\title{
Cultural-Loaded Terms in Translation of Sandalwood Death from the Perspective of Contextual Adaptation Theory
}

\author{
Jie Li \\ East China University of Science and Technology, Shanghai, China \\ Email: lijiemtr@126.com
}

How to cite this paper: Li, J. (2021) Cultural-Loaded Terms in Translation of Sandalwood Death from the Perspective of Contextual Adaptation Theory. Open Access Library Journal, 8: e7748. https://doi.org/10.4236/oalib.1107748

Received: July 10, 2021

Accepted: September 25, 2021

Published: September 28, 2021

Copyright $\odot 2021$ by author(s) and Open Access Library Inc.

This work is licensed under the Creative Commons Attribution International License (CC BY 4.0).

http://creativecommons.org/licenses/by/4.0/

\section{(c) (i) Open Access}

\begin{abstract}
Establishing an effective way of Chinese culture "Going Out" has been a common concern as Chinese comprehensive power increases. The tacit collaboration between Mo Yan and Howard Goldblatt provides an outstanding example of Chinese-English translation. Under the guidance of Contextual Adaptability Theory, this thesis conducts research on cultural-loaded terms in Sandalwood Death from the perspective of communicative context and linguistic context to expose the specific strategy Howard applied in Chinese-English translation, aiming to provide some suggestions on the reaching-out translation of Chinese work and more supporting materials on Adaptation Theory.
\end{abstract}

\section{Subject Areas \\ Culture, Linguistics}

\section{Keywords}

Cultural-Loaded Terms, Context Adaptation Theory, Linguistic Context, Communicative Context

\section{Introduction}

Chinese culture "Going Out" becomes essential access of improving soft power of China. Great emphasis has been put on the translation of Chinese works since the reform and opening up, especially after the $21^{\text {st }}$ century [1]. Mo Yan's winning of Nobel Prize in Literature in 2012 set a good example for reaching-out translation. In addition to his high level of writing skills and super storytelling ability, Howard Goldblatt's high-quality translation also matters, which provides access for English readers especially those Nobel Prize judges [2]. Based on that, 
Goldblatt is highly regarded as the "'midwife' of Mo Yan's works taking root and prospering in western world" [3], whose translation adds indelible marks of English and American literature to traditional Chinese works and provides a systematic understanding of Chinese modern and contemporary literature for westerners.

Sandalwood Death is one of Mo Yan's masterpieces which represents a civil incident struggling against colonialism on the Shandong Peninsula in the late Qing Dynasty. Taking sandalwood punishment as a clue, the novel exposes the cruelty and inhumanity of feudal monarchy and power struggles. As a representative work of Chinese-English translation, Howard Goldblatt's English version arouses domestic scholars' researches from different theories: some adopt Peter Newmark's theory to further analyze its practical application; Guo Yuhong (2015) conducts research from the perspective of "dynamic equivalence" [4]; Jia Liping and Gao Xiaona (2017) analyzes compensation adapted in the translation by Hermeneutic Theory, etc. [5]. Most of them conduct confirmatory researches by applying prevailing Western translation theories in a general perspective.

As a representative work of Chinese folk culture, culture-loaded terms cause great difficulty in translation. Under the guidance of Contextual Adaptation Theory, this thesis conducts an analysis on culture-loaded terms in Howard's translation of Sandalwood Death from the perspective of communicative context and linguistic context, aiming to dig out the strategy used in this novel and thus provide some suggestions on establishing suitable C-E translation method.

\section{Theoretical Framework}

Jef. Verschueren, founder of linguistic adaptation theory, holds that the process of using language is a process of continuous making choices [6], which is a dynamic adaptation according to different levels of psychological awareness from the aspects of context and language structure. Language choices contain three important characteristics, namely variability, negotiation, and adaptability [6]. Among them, adaptation matters most which indicates that language users can make flexible changes to meet the needs of communication and thus realize transition between different languages [7]. Linguistic adaptation mainly contains four characteristics, that is, contextual correlations of adaptability, structural objects of adaptation, and dynamics of adaptation and salience of the adaptation processes.

Translation is a process of communication requiring translator's deep understanding towards original text and adaptation to target readers' context, which is a comprehensive adaptation process to the context. Based on Verschueren, contextual adaptation consists of cultural contextual adaptation and linguistic contextual adaptation [8]. The choices of expression must be in accordance with communicative context, which includes mental world, social world, psychological world, and the language user. As for linguistic features of translation, adaptation to linguistic context contains discourse context and channel: context in- 
cludes pragmatic means such as vocabulary, rhetoric, pragmatic style and other constraints, linear arrangement of discourse, etc.; channels are divided into natural channels and artificial channels [9]. Through overall context adaptation, the translation can be highly received.

\section{Analysis}

\subsection{Communicative Context}

\subsubsection{Mental World}

According to Verschueren (2000) [6], mental world activated in language use contains cognitive and emotive elements, which requires the translator to take cognition and emotions of authors and target readers into consideration. Mo Yan' work merges folktales, history and contemporary with hallucinatory realism. Shouldering the responsibility of Chinese culture "Going Out", culture-loaded items with the local flavor in his work should be aware of when doing translation. The translator must find the balance point between the author and target readers.

1) 俺爹的嗓子, 沙䫓的西瓜, 不知道迷倒过高密东北乡多少女人。俺那死 去的娘就是迷上了他的公鸭嗓子才嫁给他做了老婆。

His voice, soft and pliable, like watermelon pulp, captivated scores of Northeast Gaomi Townshipbeauties, including my late niang, who married him solely on the strength of his voice.

There exist a large number of animal-imaged metaphors in Chinese daily expressions, which needs translators make suitable adaptation based on target readers' cognition. For instance, Chinese phrase “公鸭嗓” in case (1) refers to those people especially men with strong voices sounding like quack in some extent. Here it is used to show the uniqueness and charm of Dieh's voice-it's his voice that wins ladies' hearts. While in westerners' cognition, the sound of duck refers to talking loudly and foolishly, which is not to describe the character of human voice. Taking the cognition of target readers into account, Goldblatt omits the image. Besides, he adds adjectives "soft and pliable", helping readers understanding the connotation in the source text better.

2) 俺想起钱丁, 钱大老爷, 进士出身, 五品知县, 加分府衔, 父母官, 俺 的干爹, 你这个翻脸不认人的老猴精。

(An xiang qi qian ding, qian da ye, jin shi chu shen, wu pin zhi xian, jia fen fu xian, fu mu guan, an de gan die, ni zhe ge fan lian bu ren ren de lao hou jing)

I had thoughts of Qian Ding, our magistrate, ... but to me, this gandieh, my so-called benefactor, was a double-dealing monkey monster.

Translation can never be a single transition of linguistic signs. The hidden emotions between the lines should also be considered. “老猴精” in Chinese refers to those people good at playing tricks to get "free riding". In case (2), it implies that "my gandieh", the County Magistrate, benefited from " $\mathrm{i}$ " in daily life but when "my dieh" got into trouble, he didn't provide any help. Here, due to gandieh's high social position, "i" adopts this expression to express my com- 
plaint in a joking way. "Monkey" in Oxford Dictionary has the explanation "mischievous person", "monster" describes people with bad behaviors humorously and the modifier "double-dealing" concludes his characters. By the combination of these three words, emotions contained in the original text are expressed.

3) 俗言道不看僧面看佛面, 不看鱼面还要看水面。

(su yan dao bu kan sen mian kan fo mian, bu kan yu mian hai yao kan shui mian)

The adage goes, "If you won't do it for the monk, then do it for the Buddha; if not for the fish, then for the water."

4) 俺看到知县垂着头坐在椅子上, 好像一颗被霜打了的青苗, 无精打采, 不死不活。

The County Magistrate was still in his chair, head slumped down on his chest, like a wheat stalk weighted down after a frost, seemingly neither dead nor alive.

Except for the cognitive and emotive elements, the intention of translation also matters. Mo Yan's work is famous for its local flavor, representing the unique characteristics of Chinese folk culture. Shouldering the responsibility of promoting Chinese culture, those cultural elements should be saved and transmitted. Therefore, during the whole process of translation, Goldblatt always communicated with Mo Yan to make sure the true thoughts he wants to deliver. “不 看僧面看佛面” in case (3) comes from The Journey to the West, meaning that doing something out of consideration of somebody else. Compared with monk, "Buddha" has more rights of speech and without water, fish couldn't live. "Gandieh" Qian Ding has no duty to help "my dieh” but considering that Qian benefited a lot from "I", he should not stand back in silence. Provided that images are both understandable by westerners and Chinese, the translator adopts literal translation, reserving the original taste of the work as much as possible. So does case (4). Although the metaphor is not used as frequently as in Chinese, the wheat and frost both exist in western culture. Readers can get the implication through context. Considering the intention of the author, Goldblatt still chooses to save the image, reserving the original expressions to the maximum extent.

5) 这就叫 “炒熟黄豆大家吃, 炸破铁锅自倒霉”。

(zhe jiu jiao "chao shu haung dou da jia chi, zha po tie guo zi dao mei)

As the adage has it, "When the beans are fried, everyone eats; but if the pot is broken, you suffer the consequences alone."

6) 有菄无東打三竿, 死马当成活马医。

(you zao wu zao da san gan, si ma dang zuo huo ma yi)

You hit the tree whether there are dates or not; you treat a dead horse as if it were alive.

However, after contrasting Goldblatt' translation and Mo' version, it's found that even though the images exist in both languages, literal translation can also cause confusion. Sandalwood Death happened in late Qing Dynasty, during which time people were suppressed by feudalism and imperialism but was still insensitive and no one rose up against oppression. The Sun Bing in the novel is 
an exception. He is the person who fired the beans while others just enjoy the fruits. When the pot is broken by them, no one takes responsibility. “炒熟黄豆 大家吃, 炸破铁锅自倒霉” in case (5) is used to satirize the cowardliness of people at that time. Although reserving the original image, the translation also causes confusion. So does case (6). Separating the metaphor from the context, "You treat a dead horse as if it were alive." doesn't indicate the desperation and dilemma of "me", either. Therefore, translator's intention of letting Chinese works go global matters but communicative function should be realized first.

\subsubsection{Social World}

Social settings or institution plays an vital role in linguistic choices for it provides many principles that restrict the forms of language. Among all factors of social world, culture matters most. "'Cultural' dimension includes religious beliefs, historical backgrounds, customs, cultural traditions, the way of thinking, values, aesthetic interests etc." [[6]: p. 92]

7) 它们知道, 明天早晨, 太阳刚冒红的那个时辰, 就是它们见阎王的时候。

(ta men zhi dao, ming tian zao chen, tai yang gang mao hong de na ge shi chen, jiu shi ta men jian yan wang de shi hou)

They knew that daybreak, soon after the red rays of sun appeared, would mark the hour that they went to meet Yama, the King of Hell.

Mo Yan's work features the combination of magical realism and local culture. Religious phrases like “得了道啦, 成了仙啦” and “让她老人家显灵” plays an important role in traditional Chinese expression. Only with correct understanding towards social world of target language can translators make the most suitable choice. “阎王” refers to the deity in ancient Chinese religious myths, controlling the life of human beings. Yama in case (7), is the guardian, judge and ruler of dead in Hindu mythology while "the King of Hell" further emphasizes "the leader of devils", widely used by Christian. By adapting to western religious beliefs, the translation is more received.

8) 什么举人家的小姐, 什么翰林府里的千金, 比不上老娘一根脚指头。

(shen me ren jia de xiao jie, shen me han lin fu li de qian jin, bi bu shang lao niang yi gen jiao zhi tou)

I don't care if it's the daughter of the provincial licentiate or the apple of the Hanlin scholar's eye, they cannot compete with one of my big toes.

9) 钱丁啊钱丁, 你这个里通外国的汉奸, 老娘生了气, 就敢身背黄榜进京 告御状。

(qian ding a qian ding, ni zhe ge li tong wai guo de han jian, lao niang sheng qi le, jiu gan shen bei huang bang jin chang gao yu zhuang)

Their faces told me they meant business. Qian Ding, oh, Qian Ding, you turncoat, your illicit relations with foreigners have made me angry enough to take my grievance to the capital and accuse you of...

10）俺也想不到, 一个女流之辈俺竟然能够手持利刃杀了自己的公爹。

(An ye xiang bu dao, yi ge nv liu zhi bie an jing ran neng gou shou chi li ren sha le zi ji de gong die) 
And never could I have imagined that I, a mere woman, would take knife in hand and with it kill my own husband's father.

11）俺心里想, 不能软, 管他是真爹还是假爹, 都得先给他一个下马威, 让他知道一下姑奶奶的厉害, 省了将来在俺的面前作威作福。

(an xin li xiang, bu neng ruan, guan ta shi zhen die hai shi jia die, dou dei xian gei ta yi ge xia ma wei, rang ta zhi dao yi xia gu nai nai de li hai, sheng le jiang lai zai an de main qian zuo wei zuo fu)

I needed to give him a firm warning, whether he was a real gongdieh or not, to let him know who he was dealing with and to keep him from trying to lord it over me in the future.

12) 姑奶奶, 得罪得罪, 不知者不怪罪!

(gu nai nai, de zui de zui, bu zhi zhe bu bu guai zui)

Do not take offense, Elder Sister; I did not know.

Colorful address terms matters in Chinese culture and choices of words in translation should be in accordance with communicative context. “千金” and “小姐” in case (8) both refers to "daughter" but the difference is that the former shows more respect towards the addressee. Based on specific contexts, Howard made different lexical choices, translating “千金” into "the apple of the Hanlin scholar's eye and directly turns “小姐” into “daughter”, making out the distinction. Besides, in this novel, “老娘” and “俺” are always adapted to describe “myself", contributing to localization of characters. However, English does not have as many as address terms as Chinese. Adapting to the social world of westerners, Goldblatt diresctly turns them into “me" and “I”. So does “姑奶奶”. When it refers to naming oneself, the translator deletes it directly like case (11). If it is used to show respect and bag for mercy, free translation will be adapted like "Elder Sister" like case (12).

13）俺的丈夫赵小甲是杀狗宰猪的状元, 高密县里有名声。

(an de zhang fu zhao xiao jia shi sha gou zai zhu de zhuang yuan, gao mi xian li you ming sheng)

No one is better at butchering dogs and slaughtering pigs than my husband, Zhao Xiaojia, whose fame has spread throughout Gaomi County.

14) 据说是描龙绣风的高手, 筝琴琵琶诸般乐器样样能演奏。

(ju shuo shi miao long xiu feng de gao shou, zheng qin pi pa zhu ban yue qi yang yang yang neng yan zou)

She was reputed to be peerless in the art of embroidery and was a talented musician, proficient in instruments from the zither to the lute and balloon guitar.

“状元”, “龙” and “凤” also plays an important role in Chinese culture but as time passes by, the specific connotation may change. The meaning of “状元” are not restricted in the first name in Imperial Examination but also all works of life. In case (13), Mo Yan uses it to describe Zhao Xiaojia's good skills of killing animals. For foreigners, they are not quite familiar with Imperial Examination so literal translation here adds the burden of reading. "Is better at" is more suitable 
to target readers' cultural context. So does the translation of “描龙绣凤”. It literally means embroidering phoenix and dragon patterns as decoration but nowadays is used to describe those with fine needlework. Case (14) also adopts its general meaning- "peerless in the art of embroidery", which is not confined in dragon or phoenix. To enlarge the acceptability of translation, omitting those cultural elements unfamiliar to target readers is advisable.

\subsubsection{Physical World}

According to Verschueren, factors of time and space take a large portion in physical world. Translating Chinese into English is a kind of interlingual communication across different regions and times. Due to temporal and spatial differences between different languages, active adaptation to the physical world should be made.

15) 你这个寒冬腊月蹲锅框的小叫花子, 不是老娘替你说话, 你怎么能当 上弓箭手?

(ni zhe ge han dong la yue dun guo kuang de xiao jiao hua zi, bu shi lao niang ti ni shuo hua, ni zen me neng dang shang gong jian shou)

And you, Little Shun, a common beggar who sought warmth from a cook stand in the dead of winter, if I hadn't put in a good word for you, do you think you would now be one of his select archers?

16) 三伏天里, 干脆就淢在他爹屋里不出来了, 连党也不跟俺睡了。

He hated to leave that room, even to come to my bed during the hottest days of the year, in effect switching the roles of parent and spouse.

“腊月” is the twelfth month of the year, the coolest month all year around in China. The concept doesn't exist in English and the twelfth month is not the winter in many English-speaking countries. “三伏天” is a traditional expression of the hot days in summer according to lunar calendar but the expression doesn't exist in target language. Therefore, Howard discards the detailed month and just stresses the coldest time and hottest time to be accustomed to temporal differences in regions and cognition.

17）俺一猜就知道他是大名鼎鼎的山东巡抚袁世凯, 就是他断送了戊戌六 君子。

(an yi cai jiu zhi dao ta shi da ming ding ding de shandong xun fu yuan shi kai, jiu shi ta duan song le wu xu liu jun zi)

Yuan Shikai, the man who had ordered the execution of the Six Gentlemen of the Hundred Day's Reform of 1898.

18）他是光绪癸未科进士，与后来名满天下的刘光第同榜。

(ta shi guang xu gui mo ke jin shi, yu hou lai ming man tian xia de liu guang di tong bang)

Qian had passed the Imperial Examination with distinction, achieving one of the highest rankings, in 1883, the eighth year of the Qing Guangxu Emperor's reign, sharing honors with Liu Guangdi.

“戊戊六君子” refers to six representatives of the Hundred Day's Reform massacred by feudal die-hards. When translating the event, Goldblatt doesn't 
choose literal translation "Wu Xu Reform" but deletes the specific Chinese way of chronology unfamiliar to westerner' recognition. Besides, he also adds specific time 1898, making the time much clear. So does case (18). Apart from the description of "Guangxu Emperor' region", Goldblatt stresses the dynasty "Qing” and "the eighth year" and the year 1882 but doesn't mention “癸未”. By adapting to physical world of English-speakers, the translation is more accepted.

19）过上个十年八载, 你们的猫腔里, 没准就会有一出 “孙眉娘大闹秋千 架”呢!

(guo shang ge shi nian ba zai, ni men de mao qiang li, mei zhun jiu hui you yi chu sun mei niang da nao qiu qian jia ne)

Ten years from now, the repertoire of that Maoqiang opera of yours might well include a play called Sun Meiniang Raises Eyebrows on a Swing!

Based on Verschueren (2000) [6], the relevance of space as acontext adaptability stretched beyond mere spatial reference. Standard metaphors in areas of experience such as time, voice etc. are all included [10]. In case (19), “过上个” refers to some time in the future, which is translated into "ten years from now". The word "from now" indicates the direction in our minds, which is the spacial context contained in westerner. Besides, the general figure “十年八载” is turned into specific one "ten year", adapted to western' way of expression.

\subsection{Linguistic Context}

Linguistic context includes three aspects: contextual cohesion, intertextuality and sequencing. The differences between Chinese and English in sequencing patterns reflect their own thinking models. Just like Verschueren mentioned, the sequencing of constituent parts of sentence determines the consideration of logical and semantic ordering [6]. Cultural elements are essential during the process of communication but before that, the translation must obey the linguistic construction of target language.

20）娘娘显灵了啊, 娘娘显灵! 娘娘显灵, 保佑俺的爹吧!

(niang niang xian ling le a, niang niang xian ling! Niang niang xian ling, bao you an de die ba)

She was making her presence known; she was telling me something! Use your power, Matriarch, to protect my dieh!

21）咱去弄个叫花子来当替死鬼, 来他个偷梁换柱李代桃僵。

22) (zan qu nong ge jiao hua zi lai dang ti si gui, lai ta ge tou laing huan zhu li dai tao jiang)

We'll find a beggar to take your place, what they call stealing beams and changing pillars, to manage a bit of trickery.

Compared to Chinese, English is more concise by avoiding repetition of expression. In case (19), “显灵” appears three times but neither of them adopts same words. The first one emphasizes the phenomenon, the second focuses on action of "she" and the third expresses the prayer of "me", hoping that the magic power of “娘娘” can help “dieh”. These three ways of translation adopts the 
concise principle of target language and makes the same phrases in Chinese more understandable. Apart from substitute, omission is another way to achieve conciseness. For instance, “偷梁换柱” and “李代桃僵” are similar idioms, indicating using one thing to substitute for another. Chinese prefers to use repetition to make the sentence more powerful or to achieve symmetric structure. Here Howard deletes the abundant part “李代桃僵” and adds conclusion “manage a bit of trickery", adapting to target language's linguistic structure.

23）俺公爹头戴着红缨子瓜皮小帽、穿着长袍马裱、手捻着佛珠在院子里 晃来晃去时, 八成似一个告老还乡的员外郎, 九成似一个子孙满堂的老太爷。

In his red-tasseled skullcap and long robe, topped by a short jacket with buttons down the front, he paced the courtyard...

24）俺想起钱丁, 钱大老芧, 进士出身, 五品知县, 加分府衔, 父母官, 俺的干紊......

(an xiang qi qian ding, qian da lao ye, jin shi chu shen, wu pin zhi xian, jia fen fu xian, gu mu guan, an de gan dei)

I had thoughts of Qian Ding, our magistrate, who had claimed success at the Imperial Examination, a grade five official, almost a prefect, what's known as a County Magistrate; but to me, this gandieh, my so-called benefactor, was a double-dealing monkey monster.

Chinese emphasizes on parataxis-the arranging of clauses one after the other without connectives, which shapes the stream line form of sentence structure. The focus of sentence is shaped by semantic connection. English is hypotactic-the dependent or subordinate or relationship of clauses with connectives, which contributes to three-dimensional sentence structure. Therefore, differences in linguistic construction should also be considered when doing translation. In case (22, “戴着红缨子瓜皮小帽、穿着长袍马补、手捻着佛珠” conducts detailed description of "my dieh's" decoration successively without special focus. But in Howard's translation, "he" is chosen as the subject while images including his skullcap, short jacket etc are put relatively subordinate position. Case (23) also shows translator's adaptation to English way of sentence structure, in which sentence structure is reorganized based on the understanding towards source text.

25）窝窝囊囊活千年, 不如轰轰烈烈活三天。

(wo wo nang nang huo qian nian, bu ru hong hong lie lie huo san tian)

Better to live three days and go out in a blaze of glory than to live a thousand years as a timid soul.

26）儿媳，你的干爹已经是泥菩萨过江自身难保。

(er xi, ni de gan die yi jing shi ni pu sa guo jiang zi shen nan bao)

Maybe, but my dear daughter-in-law, your gandieh is like a clay bodhisattva who must worry about its own survival while crossing the river.

Chinese sentences are organized by the sequencing pattern of "deduction-conclusion" while English sentences follows the pattern of "conclusion-deduction", which is the reason why Howard choose "better to live three 
days” at the very beginning and “窝窝囊囊活千年” at the end. So does case (25). In Chinese, the result “自身难保” is put at the end of sentence while the in English, "worry about its own survival" is the conclusion and "crossing the river" is the deduction. Even in the culture-loaded items' translation, the linguistic distinction should also be noticed.

\section{Conclusions}

Under the background of Chinese culture "Going Out", establishing a method on the reaching-out translation is essential. Goldblatt' successful translation of Mo Yan's work provides a good reference. By conducting detailed analysis of Sandalwood Death, this thesis exposes translation strategies Howard Goldblatt applied on cultural-loaded terms, aiming to dig out some specific guidance on Chinese to English translation.

Translator functions like the bridge connecting author and readers, the duty of who is to represent the content of source text and make the translation received to the largest extent. In general, Goldblatt adapts to target readers' communicative context by domestication, transforming those culture-loaded phrases into English idioms or deleting those unnecessary modifiers directly. However, out of respect to the original author and the intention of Chinese culture "Going Out", Goldblatt also adopts literal translation, which is the reason why there exist some places hard to be understood even using familiar images. As for linguistic context, the translator rearranges sequencing patterns and a series of substitutions are used to conciseness, adapting to westerners' thinking patterns and language habits. On the whole, Glodblatt tries his best to achieve the balance between target readers and the author.

In conclusion, language use is a continuous process of making choices. Howard Goldblatt adapts literal translation to reserve unique characteristics of Chinese culture and complies with English linguistic features, weakening the strangeness of English readers at the very beginning. Through a series of choices, Howard realizes adaptation and coordination between the author and target readers, which contributes to the wide-scale acceptance of Mo Yan's work among English readers.

\section{Conflicts of Interest}

The author declares no conflicts of interest.

\section{References}

[1] 许多, 许钧. 中国典籍对外专播中的 “译出行为”及批评探索 [J]. 中国翻译, 2019(5): 130-137

[2] 张继光. 中国文学走出去的重要推手一一葛浩文[J]. 西安外国语大学学报, 2016, 24(4): 105-108.

[3] Updike, J. (2005) Bitter Bamboo-Two Novels from China. The New Yorker, 2005, No. 5, 84-87. 
[4] 郭宇虹. “动态对等”视角下分析《檀香刑》的英译本 Sandalwood Death [J]. 英语 广场(下旬刊), 2015(7): 9-11.

[5] 贾立平, 高晓娜. 阐释运作理论视角下《檀香刑》的翻译补偿研究[J]. 哈尔滨学 院学报, 2017, 38(5): 113-116.

[6] Verschueren, J. (2000) Understanding Pragmatics. Edward Arnold Ltd., London.

[7] 杨俊峰. 语境顺应与语用翻译[J]. 外语与外语教学, 2005(11): 47-50.

[8] 马卉. 语言顺应论对翻译的启示[J]. 哈尔滨工业大学学报(社会科学版), 2006, 8(5): 157-160.

[9] 卢慧泽. 文化语境顺应视角下的《生死疲劳》翻译研究[D]: [硕士学位论文]. 陕 西: 陕西师范大学, 2018 .

[10] 王涛. 政务演讲口译中的语境顺应性研究[D]: [硕士学位论文]. 内蒙古: 内蒙古 大学, 2018. 